\title{
IMPLEMENTASI POAC FUNGSI MANAJEMEN PADA ADMINISTRASI KEUANGAN DI KANTOR KECAMATAN MARISA KABUPATEN POHUWATO
}

\author{
Widya Kurniati Mohi ${ }^{1}$, Ramlah Alkatiri ${ }^{2}$, Muh. Firyal Akbar ${ }^{3}$, Isna S Baruadi ${ }^{4}$ \\ ${ }^{1,3,4}$ Program Studi Administrasi Publik Universitas Muhammadiyah Gorontalo \\ ${ }^{2}$ Program Studi Ekonomi Pembangunan Universitas Negeri Gorontalo
}

\begin{abstract}
This study aims to obtain information about the Implementation of Financial Administration at the Marisa Sub-District Office in Pohuwato Regency. The research method uses a qualitative type. Data collection techniques are done through interviews with a number of informants and observations and recording of secondary data related to research problems. The results of the study concluded that the implementation of financial administration in the planning, organizing, movement and supervision phases has not been effectively seen from human sources not professional in planning activities and budgeting, incompatibility of main tasks/function and preparation of LPJ and internet network systems which are obstacles in the reporting process. So it is expected that the government optimizes the implementation of financial administration by conducting education and training on financial administration management and increasing supervision and control.
\end{abstract}

$\begin{array}{ll}\text { Keywords } & \text { : Implementation; Financial Administration } \\ \text { Correspondence to } & \text { : widyakurniati@ umgo.ac.id }\end{array}$

\begin{abstract}
ABSTRAK
Penelitian ini bertujuan memperoleh informasi tentang Pelaksanaan Administrasi Keuangan di Kantor Camat Marisa Kabupaten Pohuwato. Metode penelitian menggunakan jenis kualitatif. Teknik pengumpulan data dilakukan melalui wawancara dengan sejumlah informan dan observasi serta pencatatan data sekunder yang berkaitan dengan permasalahan penelitian. Hasil penelitian menyimpulkan bahwa pelaksanaan administrasi keuangan dalam tahap perencanaan, pengorganisasian, pergerakan dan pengawasan belum efektif dilihat dari sumber manusia belum profesional dalam merencanakan kegiatan dan penganggaran, ketidak sesuaian tupoksi dan penyusunan LPJ serta sistem jaringan internet yang menjadi kendala dalam proses pelaporan. Maka diharapkan kepada pemerintah mengoptimalkan pelaksanaan administrasi keuangan dengan mengadakan pendidikan dan pelatihan tentang pengelolaan administrasi keuangan serta meningkatkan pengawasan dan pengontrolan.
\end{abstract}

$\begin{array}{ll}\text { Kata Kunci } & \text { : Pelaksanaan; Administrasi Keuangan } \\ \text { Korespondensi } & \text { : widyakurniati@ umgo.ac.id }\end{array}$ 


\section{BALANCE : Economic, Business, Management, and Accounting J ournal Vol. XVII No. 2 |Bulan J uli Tahun 2020}

\section{PENDAHULUAN}

Para pemberi pelayanan dituntut tidak hanya memberikan pelayanan standar namun di era kekinian pelayanan prima yang mengedepankan kualitas dibutuhkan untuk memberikan hasil yang lebih baik. Untuk menghasilkan pelayanan yang baik instansi terkait harus mampu memberikan gambaran mengenai kualitas pelayanan kepada para pegawainya baik itu dengan memberikan arahan, mengharuskan membaca pedoman dan memberikan pelatihan-pelatihan dalam upaya peningkatan kualitas pegawai itu sendiri (Mohi \& Mahmud, 2018). Pegawai yang berhasil dengan baik dalam melayani berbagai kepentingan administrasi bagi warga masyarakat, apabila mampu memahami dan melaksanakan peran sebagai orang yang diberi tanggung jawab untuk mengelola administrasi pemerintahan di tingkat kecamatan. Selanjutnya bahwa keberhasilan pegawai juga sangat bergantung pada pimpinannya, dalam hal ini pimpinan Kecamatan (Baderan \& Ingo, 2018)

Terkait dengan hal tersebut setiap instansi ataupun organisasi dalam manjalankan aktivitasnya, melakukan usahausaha agar dapat mencapai tujuan bersama yang telah ditentukan. Bahkan dalam upaya untuk mencapai tujuan tersebut banyak cara yang dilakukan, diantaranya dengan cara merumuskannya dalam sebuah program kerja, mengelola dan menata data hingga pada saat akhir pelaporan ataupun hanya sekedar membuat langkah-langkah strategis untuk mencapai tujuan tersebut (Sardi, 2017)

Sejalan dengan kebijakan otonomi daerah kecamatan bertanggung jawab dalam penyelenggaraan tugas umum pemerintahan dan melaksanakan sebagian wewenang bupati/walikota yang dilimpahkan. Dalam konteks otonomi daerah pemerintah di daerah memiliki peluang yang lebih besar untuk membantu meningkatkan kesejahteraan masyarakat. Kondisi ini terjadi karena otonomi daerah memberikan kesempatan kepada pemerintah daerah untuk berkreasi dan berinovasi dalam rangka menciptakan tatanan masyarakat yang dinamis dan sejahtera (Akbar, 2016). Hal tersebut harus dilakukan oleh kecamatan sebagai perangkat daerah sekaligus pelaksana teknis kewilayahan. Dalam menjalankan tanggung jawab tersebut, kecamatan mendapatkan dana yang diambil dari anggaran pendapatan dan belanja daerah (APBD) Kabupaten/kota. Semakin besarnya kewenangan berkontribusi terhadap membesarnya dan yang harus dikelola.situasi ini juga harus disertai dengan pemenuhan atas kepatuhan, efesiensi, efektifitas, transparansi dan akuntabilitas dalam pengelolaan keuangan.

Keuangan merupakan salah satu sumber daya yang secara langsung menunjang segala kegiatan dalam penyelenggaraan program, keuangan merupakan potensi yang sangat menentukan dan merupakan bagian yang tidak terpiahkan dalam kajian manajemen administrasi. Administrasi keuangan terdiri dari serangkaian langkah-langkah dimana danadana yang disediakan tertentu dibawah prosedur-prosedur yang menjamin dan bergunanya pemakaian dana-dana itu, bagian utama ialah menyusun anggaran,pembukuan, pemeriksaan pembukuan, pembelian dan persediaan (Purnomo, 2015)

Administrasi keuangan merupakan masalah yang cukup mendasar di setiap instansi pemerintahan atau swasta. Pelaksanaan administrasi merupakan suatu proses yang menyeluruh dan terdiri dari bermacam-macam kegiatan yang meliputi atau aktifitas dalam pelaksanaannya. Kegiatan administrasi keuangan adalah pembukuan atau kegiatan keuangan. Kegiatan administrasi ini meliputi dua hal pengurusan yaitu petama pengurusan yang menyangkut kewenanagan menentukan kebijakan menerima atau mengeluarkan uang. Pekerjaan 


\section{BALANCE : Economic, Business, Management, and Accounting J ournal}

Vol. XVII No. 2 |Bulan J uli Tahun 2020

ini dikenal dengan istilah pengurusan ketatausahaan. Pengurusan kedua menyangkut urusan tindak lanjut dari urusan yang pertama, yaitu menerima, menyimpan dan mengeluarkan uang. Pengurusan ini tidak menyangkut kewenangan menentukan, tetapi hanya melaksanakan dan dikenal dengan pengurusan bendahara. (Suardita, 2016)

Administrasi keuangan adalah suatu kegiatan perencanaan, penganggaran, pemeriksaan, pengelolaan, pengendalian, pencarian, dan penyimpanan dana yang dimiliki oleh sekelompok orang atau perusahaan.Ruang Lingkup Administrasi Keuangan terbagi menjadi 2 yaitu Administrasi Keuangan Tahunan dan administrasi Keuangan Bulanan. Administrasi Keuangan Tahunan adalah pembukuan atau akuntansi (controler) yang mempunyai fungsi pokok (recording) dan membuat laporan (reporting) tentang informasi keuangan suatu perusahaan dalam periode tahunan. Administrasi keuangan bulanan adalah pembukuan atau akuntansi (controler) yang mempunyai fungsi pokok (recording) dan membuat laporan (reporting) tentang informasi keuangan suatu perusahaan dalam periode bulanan (Bahar, 2019).

Pelaksanaan administrasi keuangan adalah usaha manusia yang meliputi penetapan cara-cara penyelenggaran pembinaan organisasi yang berkenaan dengan masalah keuangan (Setyoko, 2011). Dalam pelaksanaan penataan administrasi keuangan di Kantor Camat, penatausahaan keuangan memegang peranan yang penting dalam siklus pengelolaan keuangan suatu OPD. Kegiatan penata usahaan lebih banyak berkaitan dengan kas baik penerimaan kas atau pengeluaran. Seluruh aktivitas penerimaan dan pengeluaran kas dokumentasi Buku Kas Umum (BKU) yang dilengkapi dengan buku pembantu. Kegiatan administratif yang terkait dengan kas adalah administrasi SPP, SPM dan SP2D, pada akhir bulan, bendahara pengeluaran akan menyusun pertanggungjawaban berupa SPJ administratif dan fungsional

Kantor Camat Marisa merupakan salah satu instansi pemerintah yang menjalankan keseluruhan aspek kegiatan administrasi yang sesuai dengan prosedur dan wewenang yang berlaku. Sebuah instansi akan maju apabila administrasinya tertata dengan baik sehingga dalam penyelenggaran sebuah laporan bisa berjalan secara efektif, dari keseluruhan keuangan yang menjadi bahan dalam pertimbangan dalam sebuah pelaporan dan sebagai jalannya pembangunan sebuah organisasi. Beberapa riset sebelumnya lebih banyak fokus dalam penggunaan aplikasi pada manajemen/adminsitrasi keuangan pada lokus masing-masing, sedangkan dalam penelitian ini fokus pada keseluruhan prinsip manajemen keuangan yang ada di Kantor Camat Marisa sehingga hal ini merupakan state of the art dan kebaharuan dalam riset ini

Dalam membangun sebuah sistem manajemen keuangan yang baik diperlukan beberapa prinsip dasar kaitannya dengan manajemen dan administrasi keuangan yang baik, sebagaimana yang diungkapkan oleh George Terry bahwa ada empat fungsi pokok dalam manajemen, adalah : perencanaan, pengorganisasian, pengerakan, dan mengawasi. Empat fungsi itu sebagai berikut:

Perencanaan; yakni proses penentuan tujuan atau sasaaran yang hendak dicapai dan menetapkan jalan dan sumber yang diperlukan untuk mencapai tujuan yang seefisien dan efektif mungkin; selanjutnya Pengorganisasian, yakni merupakan aktifitas menyusun dan membentuk hubunganhubungan kerjasama antara orang perorangan sehingga terwujud satu kesatuan usaha untuk mencapai tujuan-tujuan yang telah ditetapkan; selanjutnya Pergerakan /Pelaksanaan, dapat didefinisikan sebagai keseluruhan proses pemberian dorongan bekerja kepada bawahan sedemikian rupa 


\section{BALANCE : Economic, Business, Management, and Accounting J ournal}

Vol. XVII No. 2 |Bulan J uli Tahun 2020

sehingga mereka mau berkerja dengan ikhlas demi tercapainya tujuan organisasi dengan efien dan ekonomis, dan yang terakhir Pengawasan yakni proses memonitor aktifitas-aktifitas untuk mengetahui apakah individu-individu dan organisasi itu sendiri memperoleh dan memamfaatkan sumbersumber pendidikan secara efekftif dan efisien dalam rangka mencapai tujuannya, dan memberikan kolerasi apabila tidak tercapai (Terry \& Smith, 2013)

Dipilihnya penataan pada administrasi keuangan karena peneliti ingin menganalisa bagaimana pemerintah kecamatan dapat menata penyelenggarakan admnistrasi keuangan dari perencanaan, penyusunan sampai pada pelaporan dengan baik dan benar sehingga berperan penting sebagai alat pengawasan dan pengendalian kegiatan pengelolaan atau penataan keuangan.

Hasil observasi awal yang ditemukan oleh peneliti di Kantor Camat Marisa Kabuapaten Pohuwato ditemukan masih terdapat permasalahan dalam penataan administrasi keuangan, dilihat dari pengeluaran tidak sesuai dengan rencana anggaran, sebagaimana dijelaskan sebelumnya wewanang camat adalah mengurus kepentingannya sendiri akan tetapi berdasarkan prosedur yang telah diatur akan tetapi semua pengeluaran tidak sesuai dengan anggaran yang diberlakukan sehingga laporan pertanggung jawaban tidak sesuai dengan peraturan sebenarnya.

Begitupun dengan nota-nota pengeluaran yang tidak sesuai dalam hal ini berbeda dengan yang tertera pada buku kas pengeluaran, sehingga pada saat pelaporan nota tersebut harus di perbaiki dan dilakukan pengeceakan satu-persatu yang mempelambat suatu proses pengerjaan yang seharusnya dikerjakan tanpa mengulanginya. Hal lainnya mengenai SPJ desa yang dimasukkan ke kantor camat banyak yang tidak sesuai ketika dilakukan verifikasi. Ini menjadi pertanggung jawaban pemerintah agar bisa memberikan suatu pelatihan atau pengembangan sumber daya manusia untuk menunjang keberhasilan suatu organisaasi atau instansi.Beberapa gambaran yang telah dijelaskan menunjukkan terdapat masalah yang terjadi khgususnya dalam pengadministrasian keuangan di Kantor Camat Marisa sehingga hal ini yang mendorong peneliti untuk melihat fenomena yang terjadi untuk mengungkap fakta yang sebenarnya terjadi. Beberapa penelitian terdahulu terkait dengan tema riset ini sudah ditulis oleh beberapa peneliti sebelumnya seperti yang dilakukan oleh Rahmania tentang Pelaksanaan Administrasi keuangan di Madrasah Aliyah Hasanah Pekan baru, dengan tujuan penelitiannya untuk mengetahui pelaksanaan administrasi keuangan di Madrasah Aliyah Hasanah Pekan baru (Rahmaniah, 2011). Selanjutnya penelitian yang dilaksanakan oleh Nurul Huda tentang Aplikasi pengelolaan administrasi keuangan sekolah SMK Sadamiyyah Bangsri Waterfall. Tujuan penelitian untuk menghasilkan suatu sistem berbasis web tentang informasi keuangan di sekolah SMK Sadamiyyah Bangsri Waterfall (Huda, 2016).

\section{METODE PENELITIAN}

Penelitian ini dilakukan dengan memilih lokasi Camat Marisa Kabupaten Pohuwato. Pendekatan penelitian ini adalah penelitian kualitatif dengan jenis penelitian deksriptif. Berdasarkan sumbernya, data penelitian dapat dikelompokkan dalam dua jenis yaitu data primer dan data sekunder. Data primer adalah data yang diperoleh atau dikumpulkan oleh peneliti secara langsung dari sumber datanya, yaitu Aparat di Kantor Camat Marisa, maupun struktur lain yang terlibat, kemudian dikembangkan dengan kata-kata/ ucapan lainnya yang terkait dengan 
perkembangan informasi yang diperoleh peneliti melalui observasi lapangan, pengamatan dan wawancara pada semua subyek tersebut di atas. Adapun informan dalam penelitian ini terdiri dari : Camat Marisa; Sekretaris Camat; Kepala Seksi; Staff 3; Bendahara.

Selanjutnya data sekunder adalah data yang diperoleh atau dikumpulkan peneliti dari berbagai sumber yang telah ada dengan dokumen yang terkait dengan Data Aparat, Profil Kantor Camat Marisa dan jurnal penelitian.

\section{HASIL PENELITIAN}

Penelitian ini merupakan penelitian yang bersifat deskriptif tentang pelaksanaan administrasi keuangan di Kantor Camat Marisa Kabupaten Pohuwato, dalam penelitian ini peneliti berusaha untuk menggali, mengungkapkan kemudian mendeskripsikannya. Hasil penelitian ini berupa data-data yang diperoleh melalui wawancara, dokumentasi dan informasi. Yang mengemukakan tentang bagaimana pelaksanaan administrasi keuangan,yang diteliti melalui 4 indikator oleh George R. Terry yaitu : Perencanaan, pengorganisasian, pergerakan dan pengawasan.

Hasil wawancara untuk indikator pertama yakni perencanaan ditanyakan kepada Camat, Bendahara dan beberapa staff kecamatan mengenai protap atau prosedur ketetapan yang akan menjadi acuan dalam pelaksanaan administrasi keuangan di Kantor Camat Marisa. Berdasarkan hasil wawancara yang didapatkan dapat disimpulkan bahwa proses penentuan tujuan/sasaran yang hendak dicapai dalam administrasi keuangan berjalan sesuai dengan prosedur yang berlaku dari pembuatan SK sampai pada penerbitan Dokumen daftar Pelaksanaan anggaran, tetapi belum efektif dan efesien karena dalam pelaksanaan kurang memenuhi yang menjadi tujuan dan sasaran, hal ini disebabkan kurangnya dana yang ada.

Selanjutnya untuk indikator pengorganisasian yang berfokus dalam penyusunan dan pembentukan hubunganhubungan kerjasama antar bidang untuk mencapai tujuan yang telah ditetapkan dalam pelaksanaan administrasi keuangan. Berdasarkan uraian hasil wawancara dapat disimpulkan bahwa dalam pengorganisasian penyusunan dan pembentukan hubunganhubungan kerjasama antar bidang untuk mencapai tujuan yang telah ditetapkan dalam pelaksanaan administrasi keuangan berjalan dengan baik meskipun dalam hal penataan mengenai keuangan dana dan sumber daya manusia yang belum professional dalam hal penganggaran dan ketidaksesuaian tupoksi.

Selanjutnya untuk indikator pergerakan, Pergerakan yang dimaksud dalam tahap ini bagaimana bentuk motivasi yang diberikan oleh seorang pimpinan organisasi dalam mendorong pelaksanaan administrasi keuangan di Kantor Camat marisa. Berdasarkan uraian hasil wawancara yang ditemukan dapat disimpulkan bahwa dalam pelaksanaan administrasi keuangan pada tahap pergerakan ini berjalan tetapi belum efektif karena pemberian reward terkait kinerja kadang disalahgunakan.

Yang terakhir untuk indikator pengawasan. Berdasarkan hasil wawancara diatas dapat disimpulkan bahwa pada tahap pengawasan ini pelaksanaan administrasi keuangan belum efektif, karena masih ada kendala-kendala yang ditemukan dalam hal pelaporan. Laporan yang dimasukkan belum memenuhi standar LPJ sebagaimana yang telah ditetapkan dalam peraturan dan laporan kegiatan dan jaringan internet yang tidak mendukung dalam pembuatan laporan kegiatan. 


\section{BALANCE : Economic, Business, Management, and Accounting J ournal Vol. XVII No. 2 |Bulan J uli Tahun 2020}

\section{PEMBAHASAN}

Komponen yang sangat penting dalam jalannya roda pemerintahan adalah adanya system keuangan yang dikelolah secara tertib sehingga menghasilkan kesejahteraan masyarakat yang diharapkan. Olehnya itu keuangan negara sangat diharapkan untuk dapat dikelola secara tertib sesuai dengan peraturan perundangundangan yang berlaku. Laporan keuangan negara sebagai bentuk tanggung jawab kepada masyarakat agar dapat dipercaya maka diperlukan kualitas pemeriksaan laporan keuangan yang baik oleh Lembaga auditor yang independent sebagai elemen penting dalam menemukan berbagai pelanggaran entitas yang diperiksa dalam mengelola keuangannya. Kualitas hasil pemeriksaan merupakan kualitas kerja auditor yang ditunjuk dengan laporan hasil pemeriksaan yang dapat diandalkan berdasarkan standar yang telah ditetapkan (Darmadi \& Thaha, 2019)

Pengelolaan keuangan negara adalah keseluruhan kegiatan pejabat pengelola keuangan negara sesuai dengan kedudukan dan kewenangannya, yang meliputi perencanaan, pelaksanaan, pengawasan, dan pertanggungjawaban. Prinsip dasar dalam pengelolaan keuangan negara merupakan bagian dari pelaksanaan pemerintahan, dengan memaksimalkan keuangan yang tersedia, yang diorientasikan pada pembiayaan seluruh kegiatan (program) yang telah ditetapkan (Anggara, 2016)

Administrasi Keuangan Adalah kegiatan yang berkenaan dengan pencatatan, penggolongan, pengolahan, penyimpanan, pengarsipan terhadap seluruh kekayaan Negara termasuk di dalamnya hak dan kewajiban yang timbul karenanya baik kekayaan itu berada dalam pengelolaan bankbank pemerintah, yayasan-yayasan pemerintah, dengan status hukum publik ataupun privat, badan-badan usaha Negara dan badan-badan usaha lainnya dimana pemerintah mempunyai kepentingan khusus serta terikat dalam perjanjian dengan penyertaan pemerintah ataupun penunjukkan pemerintah. Administrasi keuangan terdiri dari serangkaian langkah-langkah dimana dana-dana disediakan begi pejabat-pejabat tertentu dibawah prosedur-prosedur yang akan menjamin sah dan berdaya-gunanya pemakaian dana-dana itu. Bagian utama ialah menyusun anggaran belanja, pembukuan, pemeriksaan pembukuan, pembelian dan persediaan. (Tjandra. W.R, 2019)

\section{Perencanaan}

Perencanaan merupakan alat pertama dalam proses manajemen. Secara sederhana, perencanaan merupakan cara rasional dan sistematik dalam meramalkan masa depan sebuah organisasi atau merupakan sebuah proses dalam persiapan menghadapi perubahan dengan merumuskan tindakan di masa depan Perbedaan antara manajer yang sukses dan yang tidak sukses terletak pada prosedur perencanaannya.

Sistem pengaturan dan penyelenggaraan perencanaan tata ruang serta realisasi rencananya; sistem ini merupakan suatu proses dan prosedur yang melibatkan berbagai lembaga pemerintahan, swasta dan masyarakat yang terkait di wilayah perencanaan, proses perencanaan dan pengaturan pelaksanaan segala kegiatan atau tindakan yang diperlukan untuk mengefektifkan atau mengimplementasikan perencanaan; administrasi perencanaan merupakan bagian yang sangat penting diproses perencanaan dan realisasi rencana, sehingga perlu dipahami oleh seorang perencana.

Melalui perencanaan, para karyawan dapat mempelajari apa yang ingin dicapai oleh sebuah organisasi dan kemudian mereka membuat keputusan untuk menjamin kebijakan internal, peraturan, kinerja, struktur, produk dan pengeluaran bisa sejalan 


\section{BALANCE : Economic, Business, Management, and Accounting J ournal}

Vol. XVII No. 2 |Bulan J uli Tahun 2020

dengan hasil yang ingin dicapai. Berdasarkan

kesimpulan sebelumnya bahwa proses penentuan tujuan/sasaran yang hendak dicapai dalam administrasi keuangan berjalan sesuai dengan prosedur yang berlaku dari pembuatan SK samapai pada penerbitan Dokumen daftar Pelaksanaan anggaran, tetapi belum efektif dan efesien karena dalam pelaksanaan suatu tujuan tidak secara langsung dapat diwujudkan terhambat pada kurangnya dana yang ada. Menurut hasil observasi peneliti dilapangan, bahwa pelaksanaan administrasi keuangan di kantor Camat Marisa masih perlu ada pembimbingan khusus kepada sumber daya manusia yang ada di kantor camat Marisa, seperti halnya pengaturan buku-buku kas yang seharusnya ada dalam bentuk nyata bukan pada komputer.

Dari konsekuensi tersebut maka diharapkan kepada pemerintah selaku pembuat kebijakan, untuk bisa membangun komunikasi yang baik agar dalam suatu perencanaan program atau kegiatan bisa tersusun dengan baik dan jelas sehingga mencapai suatu sasaran dan tujuan yang diinginkan.

2. Pengorganisasian

Pengorganisasian merupakan langkah ke arah pelaksanaan rencana yang telah disusun sebelumnya. Jadi kegiatan pengorganisasian merupakan fungsi organik yang kedua dalam manajemen. Dalam fungsi pengorganisasian terdapat sekelompok orang yang mau bekerja sama, ada tujuan yang hendak dicapai, ada pekerjaan yang akan dikerjakan, ada pembagian tugas yang jelas, pengelompokan kegiatan, menyediakan alatalat yang dibutuhkan untuk aktivitas organisasi, ada pendelegasian wewenang antara atasan dan bawahan dan pembuatan struktur organisasi yang efektif dan efisien. Adapun proses organizing, meliputi berbagai rangkaian kegiatan yang bermula pada orientasi atas tujuan yang direncanakan dan berakhir pada saat kerangka organisasi yang tercipta terlengkapi dengan prosedur dan metode kerja, kewenangan, personalia serta ketersediaan peralatan yang dibutuhkan. Proses pembagian susunan kerja dalam organisasi, penempatan tenaga kerja secara obyektif yang dilakukan demi perencanaan, pelaksanaan dan pembagian kerja yang tepat.

Berdasarkan hasil kesimpulan pada uraian hasil wawancara sebelumnya disimpulkan bahwa dalam pengorganisasian penyusunan dan pembentukan hubunganhubungan kerjasama antar bidang untuk mencapai tujuan yang telah ditetapkan dalam pelaksanaan administrasi keuangan berjalan dengan baik meskipun dalam penganggaran belum sesuai dengan sasaran dan target yang ada..

Menurut observasi peneliti selama dilapangan pengorganisasian kerja sudah sesuai dengan struktural yang ada namun belum menunjukkan kinerja yang baik dalam artian struktur sudah jelas tapi tidak dengan fungsinya. Dalam hal pencatatan administrasi keuangan belum tertata dengan baik karena dilihat dari buku kas masuk sama buku kas keluar tidak jelas pencatatannya dan paling diketahui oleh sekretaris.

Untuk menyikapi hal tersebut, pihak yang berwenang harus bisa merencanakan dan membentuk dengan jelas sistem dan struktural yang ada sehingganya dapat dilihat dengan jelas tupoksi yang ada dikantor camat dan pelaksanaan administrasi tertata dengan baik.

3. Pergerakan

Pergerakan atau Actuating adalah suatu tindakan untuk mengusahakan agar semua anggota kelompok berusaha untuk mencapai sasaran yang sesuai dengan perencanaan manejerial dan usaha-usaha organisasi. Jadi actuating artinya menggerakkan orang-orang agar mau bekerja dengan sendirinya atau dengan kesadaran secara bersama-sama untuk mencapai tujuan dikehendaki secara efektif. 

Vol. XVII No. 2 |Bulan J uli Tahun 2020

Dalam hal ini yang dibutuhkan adalah kepemimpinan. Pergerakan juga merupakan pelaksanaan untuk bekerja. Untuk melaksanakan secara fisik kegiatan dari aktivitas tesebut, maka pimpinan mengambil tindakan-tindakannya kearah itu. Seperti : Leadership (pimpinan), perintah, komunikasi dan conseling (nasehat).

Berdasarkan hasil wawancara pada hasil penelitian disimpulkan bahwa dalam pelaksanaan administrasi keuangan pada tahap pergerakan ini berjalan sesuai dengan apa yang diharapkan tetapi belum efektif karena pemberian apresiasi kadang disalahgunakan.

Menurut hasil observasi peneliti di lapangan dalam hal pelaksanaan administrasi keuangan di Kantor Camat Marisa masih perlu ditingkatkan, karena peneliti melihat admnistrasi yang belum tertata dengan baik contohnya pembuatan LPJ tidak sesuai dengan aturan yang ada kadang dilebihkan kadang dikurangi.

Untuk konsisi ini, upaya untuk menjadikan perencanaan menjadi kenyataan, dengan melalui berbagai pengarahan dan motivasi agar setiap pegawai dapat melaksanakan kegiatan secara optimal sesuai dengan peran, tugas dan tanggung jawabnya.

4. Pengawasan

Pengawasan merupakan salah satu fungsi manajemen yang diharapkan mampu mencegah timbulnya penyimpangan atau kesalahan dalam pelaksanaan. Hal ini perlu dilakukan sebagai usaha sistematik untuk menetapkan standar pelaksaan dengan tujuan perencanaan, merancang sistem informasi, umpan balik, membandingkan kegiatan nyata denagn standar yang telah ditetapkan sebelumnya, menentukan dan mengatur penyimpangan-penyimpangan, serta mengambil koreksi yang diperlukan untuk menjamin bahwa semua sumber daya sekolah dipergunakan dengan cara yang paling efektif dan efisien dalam pencapaian tujuan sekolah.
Dengan pengawasan (controlling) diharapkan penyimpangan yang mungkin terjadi dapat ditekan sehingga kerugian dapat dihindari.

Untuk itu, Kepala camat dituntut untuk memahami secara garis besar pekerjaan yang dilakukan oleh pelaksana administrasi keuangan, dan paham peraturan-peraturan pemerintah yang mengatur tentang penggunaan dan pertanggungjawaban serta pengadministrasian uang Negara.

Berdasarkan hasil wawancara pada hasil penelitian sebelumnya disimpulkan bahwa pelaksanaan pengawasan dministrasi keuangan belum efektif, karena masih ada kendala-kendala yang ditemu dalam hal pelaporan.

Berdasarkan hasil pengamatan dil apangan dimana pengawasan yang dilakukan oleh pihak-pihak terkait seperti inspektorat dan lembaga lainnya sudah bekerja dengan baik namun kenyataan di lapangan berbeda setelah ditemui ada data-data yang tidak lengkap. Untuk menyikapi hal tersebut, pihak yang berwenang harus memberikan pengawasan atau pengontrolan secara professional atau tegas, agar setiap organisasi atau sumber daya manusia yang ditunjuk atau berkaitan bisa meningkatkan kinerja dan memperbaiki sistem pelaksanan administrasi yang lebih baik lagi

\section{KESIMPULAN}

Berdasarkan uraian hasil penelitian dan pembahasan yang telah diuraikan maka dalam penulisan ini dapat disimpulkan bahwa secara umum pelaksanaan administrasi keuangan masih kurang maksimal, hal ini dibuktikan dengan hasil penelitian yang diteliti melalui empat indikator :

Untuk Perencanaan bahwa pelaksanaan administrasi keuangan pada tahap pengorganisasian belum sepenuhnya dikatakan efektif karena masih perlu meningkatkan profesionalisme dalam merencanakan kegiatan yang sesuai dengan 

Vol. XVII No. 2 |Bulan J uli Tahun 2020

tujuan awal yang telah ditetapkan; Pengorganisasian administrasi keuangan dikantor camat Marisa belum baik dalam hal penetapan buku-buku mengenai keuangan dan sumberdaya manusianya yang belum professional dalam penganggaran dan ketidak sesuaian tupoksi; Pergerakan atau motivasi dalam pelaksanaan administrasi masih perlu ditingkatkan lagi, sebab pemberian apresiasi pada sumber daya manusia kadang tidak sesuai dengan penghargaan yang diberikan; Pengawasan pada pelaksanaan administrasi keuangan dikantor camat sudah berjalan dengan baik, namun perlu perbaikan dalam penyusunan LPJ yang sesuai dengan aturan yang telah ditetapkan dan sistem jaringan internet yang menjadi kendala dalam proses pelaporan.

\section{DAFTAR PUSTAKA}

Akbar, M. F. (2016). Analisis Peran Kepemimpinan Camat Di Kantor Kecamatan Bongomeme Kabupaten Gorontalo. JAKPP (Jurnal Analisis Kebijakan \& Pelayanan Publik), 1(2), 158168.

https://www.neliti.com/publications/98246/a nalisis-peran-kepemimpinan-camat-dikantor-kecamatan-bongomeme-kabupatengoront

Anggara, S. (2016). Administrasi Keuangan Negara. In Pustaka Setia Bandung. Pustaka Setia Bandung.

Baderan, U. S., \& Ingo, Y. (2018). Kinerja Pegawai dalam Pelayanan Administrasi di Kantor Kecamatan Boliyohuto Kabupaten Gorontalo. Publik (Jurnal Ilmu Administrasi), 6(2), 127-134.

Bahar, A. (2019). ANALISIS PENGELOLAAN ADMINISTRASI KEUANGAN PADA KANTOR KECAMATAN MAPPAKASUNGGU. Profitability Fakultas Ekonomi Dan Bisnis, 2(1), 22-36.

Darmadi, D., \& Thaha, R. (2019). Analisis Kualitas Pemeriksaan Pengelolaan Keuangan Negara oleh Badan Pemeriksa Keuangan Republik Indonesia (BPK-RI)
Perwakilan Sulawesi Selatan. Publik (Jurnal Ilmu Administrasi), 8(1), 75-88.

Huda, N. (2016). APLIKASI PENGELOLAAN ADMINISTRASI KEUANGAN SEKOLAH SMK SADAMIYYAH BANGSRI JEPARA MENGGUNAKAN METODE WATERFALL [Universitas Muria Kudus]. In Universitas Muria Kudus. https://eprints.umk.ac.id/6352/1/Hal_judul.p df

Mohi, W. K., \& Mahmud, I. (2018). Kualitas Pelayanan Publik di Desa Potanga Kecamatan Boliyohuto Kabupaten Gorontalo. Publik: (Jurnal Ilmu Administrasi), 6(2), 102. https://doi.org/10.31314/pjia.6.2.102110.2017

Purnomo, I. A. (2015). Sistem Administrasi Keuangan Sekolah Dengan Menggunakan Java (Studi Kasus: Di SMA Muhammadiyah 4 Andong Boyolali).

Rahmaniah. (2011). PELAKSANAAN ADMINISTRASI KEUANGAN DI MADRASAH ALIYAH HASANAH PEKANBARU. In Universitas Islam Negeri Sultan Syarif Kasim Riau.

Sardi, S. (2017). Pengaruh Gaya Kepemimpinan Transformasional Dan Transaksional Terhadap Kinerja Bawahan Melalui Kepuasan Kerja. JBTI : Jurnal Bisnis Teori Dan Implementasi, 8(1), 1-11. https://doi.org/10.18196/bti.81083

Setyoko, P. (2011). Akuntabilitas Administrasi Keuangan Program Alokasi Dana Desa (ADD). Jurnal Ilmu Administrasi Negara, 11(1), 14-24. https://ejournal.unri.ac.id/index.php/JIANA/ article/view/589

Suardita, I. K. (2016). Ilmu Administrasi Negara. Diktat: Univeristas Udayana, 71. http://ir.obihiro.ac.jp/dspace/handle/10322/3 933

Terry, G. R., \& Smith, J. (2013). Prinsip-prinsip manajemen. Bumi Aksara.

Tjandra. W.R. (2019). Administrasi Keuangan. Grasindo. 
BALANCE : Economic, Business, Management, and Accounting J ournal Vol. XVII No. 2 |Bulan J uli Tahun 2020 